\title{
Lumen
}

Selected Proceedings from the Canadian Society for Eighteenth-Century Studies

\section{Die schöne Seele: Wieland, Schiller, Goethe}

\section{Jane Curran}

Volume 27, 2008

North America at the Crossroads of European Cultures in the Eighteenth Century

L’Amérique du Nord au Carrefour des cultures au XVIII ${ }^{\mathrm{e}}$ siècle

URI : https://id.erudit.org/iderudit/1012051ar

DOI : https://doi.org/10.7202/1012051ar

Aller au sommaire du numéro

Éditeur(s)

Canadian Society for Eighteenth-Century Studies / Société canadienne d'étude du dix-huitième siècle

ISSN

1209-3696 (imprimé)

1927-8284 (numérique)

Découvrir la revue

Citer cet article

Curran, J. (2008). Die schöne Seele: Wieland, Schiller, Goethe. Lumen, 27, 75-84. https://doi.org/10.7202/1012051ar

Copyright (c) Canadian Society for Eighteenth-Century Studies / Sociéte canadienne d'étude du dix-huitième siècle, 2009
Ce document est protégé par la loi sur le droit d'auteur. L'utilisation des services d'Érudit (y compris la reproduction) est assujettie à sa politique d'utilisation que vous pouvez consulter en ligne.

https://apropos.erudit.org/fr/usagers/politique-dutilisation/ 


\section{Die schöne Seele: Wieland, Schiller, Goethe}

Christoph Martin Wieland (1733-1813) expressly mentions the ideal of the beautiful soul in referring to his complex fictitious character Danae, who appears in the novel Geschichte des Agathon (1766-67). The narrator of this novel, in what were for the time innovative addresses to the reader, digresses from the plot at various junctures in order to discuss various topics that arise from episodes in the narrative. Among these topics the favourite is probably Schwärmerei, that rather perplexing excess of enthusiasm, but another diversion concerns the ins and outs of the thoroughly fashionable eighteenth-century concept of the "schöne Seele". Danae is not the only personification of this concept to be found in the pages of Wieland's fictional works. Although Wieland does not directly claim this for her, the morally and intellectually balanced heroine of his narrative poem Musarion, who is instrumental in helping others overcome a one-sided extreme stoicism in order to achieve a similar balance, could be seen as another embodiment of the schöne Seele, the quintessential Enlightenment figure.

Friedrich von Schiller (1759-1805) arrives at a description of the schöne Seele as a theoretical visible union of duty and inclination, grace and dignity in his essay Über Anmut und Würde, a work in which he shakes himself free from Kant's influence and takes a different route. Having carefully delineated the circumstances and conditions necessary for that aesthetic and ethical phenomenon, grace, to be present in a person, Schiller turns his attention to analyzing the restraints required by dignity. Schiller's essential method for bringing the two spheres together involves the containment of extreme tendencies by means of balancing one against the other. For Schiller, the goal is reached when restraint and moderation have become second nature, a state he refers to as the beautiful soul.

Johann Wolfgang von Goethe (1749-1832) introduces yet another way of treating the topic of the beautiful soul when he uses the first-person narrative voice to recount the trials, doubts and temptations that consti- 
tute Book Six of his novel Wilhelm Meisters Lehrjahre: the "Bekenntnisse einer schönen Seele" (Confessions of a Beautiful Soul). The other characters who read the memoirs of the beautiful soul find a reflection of their own routes through life and derive consolation from the harmony and resignation achieved at the end. In each case, the condition known as "beautiful soul" arises out of a struggle; it is not a gift bestowed, but a delicate balance that requires willpower to maintain.

Several times in his novel Geschichte des Agathon, and always in his customary semi-serious manner, Wieland makes use of the term "schöne Seele", often in the plural. For example, during one of his repeated appeals to his readers not to dismiss this work as mere fiction, he reassures us that his characters Agathon and Danae are personages just as historical as "Brutus, Porcia und hundert andere"(Brutus, Portia and a hundred others) and hopes likewise that the work will never be read by anyone "der keine schöne Seelen glaubt" (who does not believe in beautiful souls), ${ }^{1}$ as though the magic will fail if the reader is not prepared to avow a belief in fairies, as a child might for performances of Peter Pan! Sometimes there seems to be a sort of secret society of schöne Seelen, whose members intuitively recognize each other by their goodness and sympathy. By describing Danae, an undeniably flawed heroine, as a "schöne Seele", virtuous by nature, in possession of an innate sense of the good and the beautiful, and able to carry out society's moral demands with a natural ease, he sets up the role of chance against which both she and, later on, Goethe's schöne Seele have to struggle. ${ }^{2}$ The narrator of Geschichte des Agathon explains how "Eine schöne Seele kann sich verirren, kann ... getäuscht werden" (a beautiful soul can get lost, can ... be deceived" but insists that this does not alter her status. Fallibility seems to be something of a precondition of the beautiful soul's existence in each of her corporeal instances. ${ }^{3}$

A glance at Wieland's essay "Von schönen Seelen," ${ }^{4}$ published in the Teutscher Merkur in 1774, provides more examples of Wieland's wit and ample evidence of his erudition, but no clearly stated formal quali-

1 All references are taken from C.M Wieland, Werke (Frankfurt: Deutscher Klassiker, 1986, vol 3). All English translations are my own. 548

2664

3664

4 Miscellanien "Von schönen Seelen" 310-321 Der Teutsche Merkur vol V, 1774. Confusingly, the Akademie-Ausgabe reproduces this with the title "Antwort auf die Frage "Was ist eine schöne Seele?" and the Frankfurter-Ausgabe identifies the volume as 1774 vol.I. 
ties to circumscribe the schöne Seele. Taking aim at reviewers, Wieland writes that his understanding of what constitutes a schöne Seele should be evident to anyone who has read his works and has become familiar with the heroines he names: Panthea, Psyche, Danae and Olinde; but then he adds (with his customary humour) that one cannot of course expect a reviewer actually to have read the works under review! Instead of identifying the characteristics of those of his heroines who belong to the category of schöne Seele, Wieland proceeds to summarize incidents from one of his favourite works, Xenophon's Cyropedia, in which it seems clear to him that the author fully intended to paint a character who embodied the principles of the schöne Seele.

In one of the episodes Wieland recounts from his reading of Xenophon, the young wife of Tigranes was abducted by Cyrus, but subsequently returned to her husband, as a consequence of his intervention on her behalf. Upon her return, the two men also sealed a bond of friendship. Invited to join Tigranes in complimenting his new friend on his good qualities and fine physique, the wife replied that she only had eyes for her husband, who had offered to sacrifice his own soul if it would save her. With these words, she expresses an attitude balanced between the demands of head and heart and establishes her credentials as a beautiful soul.

Again, the case is based on example rather than analysis and it is built on the assumption that historical circumstances take a back seat where moral issues are concerned. From the viewpoint of Wieland's somewhat idiosyncratic historical understanding of "cosmopolitanism", then, the schöne Seele is not exclusively an Enlightenment construct; it is a concept that emerges with equal clarity at various historical-cultural junctures. In another non-fictional work, however, the "Akademie zur Bildung des Verstandes und Herzens junger Leute" (1755/56), Wieland draws on an intimate knowledge of ancient sources to explain his understanding of the concept of kalokagathia as the epitome of all that makes humans morally and aesthetically superior to animals, but concedes that living examples of kalokagathia are few and far between, and a perfect example of this condition is merely an abstraction that could never actually exist. ${ }^{5}$

Wieland's cosmopolitan ideal notwithstanding, there is implicit in this essay a differentiation between the ancient concept of kalokagathia

5 Christoph Martin Wieland, "Plan einer Akademie zur Bildung des Verstandes und des Herzens junger Leute" Gesammelte Schriften Akademie Ausgabe. Berlin:Weidmann 1909, 4:183. 
as it is found in Platonic sources - the dialogues Phaedrus and Symposium - and the modern cultural ideal of the schöne Seele. In the modern world the beautiful soul is not an abstract model to strive towards, unattainable by definition and always remote from ordinary life; it is a less static ideal and one that can from time to time be realized. A schöne Seele develops in interaction with others and in response to events. It is not simply a hypothetical construct, and its flexibility, which might, by a less charitable observer, be construed as a sign of weakness or instability, is crucially bound up with the eighteenth-century ideals of Bildung, self-cultivation and progressive development. This double emphasis on the individual and society as a whole also characterizes the concept presented by Rousseau in Julie ou la nouvelle Héloïse, a source considered by some scholars as seminal for the concept of the beautiful soul in Europe. ${ }^{6}$ Perhaps Wieland was right to shy away from laying down the conditions for the modern version of kalokagathia, then, because, at least in his writings, the schöne Seele lends herself more readily to a discursive narrative context than to a precise theoretical prescription. In his study The Beautiful Soul, Robert Norton points out the greater psychological immediacy and concreteness of detail that a novelistic setting offers, and concludes that "the beautiful soul and the novel were made for each other".

It is already evident that the task of modifying an ancient Greek philosophical concept was not something that Wieland, with his preference for irony and entertainment in a well-informed historical framework, would attempt alone. His interest in Shaftesbury is well documented ${ }^{8}$ and it was Shaftesbury who reconstituted kalokagathia to include the aesthetic principles of harmony and symmetry as well as ethical sensibility in society and the individual. ${ }^{9}$ In his "Inquiry Concerning Virtue or Merit", Shaftesbury does apply the word beauty to physical form, but he also applies it to moral constitution, and to the social order as well.

6 See Maximilian Bergengruen, Schöne Seelen, groteske Körper. Jean Pauls ästhetische Dynamisierungen der Anthropologie (Hamburg: Meiner, 2003).

7 Robert E. Norton, The Beautiful Soul: Aesthetic Morality in the Eighteenth Century (Ithaca: Cornell University Press, 1995) 139.

8 K.-H. Schwabe, "Bemerkungen zur Wirkung Shaftesburys auf C.M. Wieland". Wieland-Kolloquium Edited by Thomas Köhle. Halberstadt, 1983. 185-89.

9 W. Grosse, 'Kalokagathia', Historisches Wörterbuch der Philosophie. Basel/Stuttgart: Schwabe, 1979. vol. 4682. 
The case is the same in the mental or moral subjects as in the ordinary bodies or common subjects of sense. The shapes, motions, colours and proportions of these latter being presented to our eye, there necessarily results a beauty or deformity, according to the different measure, arrangement, and disposition of their several parts. So in behaviour and actions, when presented to our understanding, there must be found, of necessity, an apparent difference, according to the regularity or irregularity of the subjects. ${ }^{10}$

The principle of balance, or the mean established between extreme states which so often occurs in Wieland's narrative works, can readily be identified in Shaftesbury's insistence on proportion:

It is impossible we can advance the least in any relish or taste of outward symmetry and order, without acknowledging that the proportionate and regular state is the truly prosperous and natural in every subject. The same features which make deformity create incommodiousness and disease. And the same shapes and proportions which make beauty afford advantage by adapting to activity and use. ${ }^{11}$

There was no shortage of philosophical discussion about the schöne Seele in the eighteenth century, and in choosing the narrative path Wieland embarked on a route more suited to his own disposition and marked by fewer pitfalls.

Chief among the dangers inherent in philosophical debate about the schöne Seele was the suggestion that beauty, applied now more narrowly to the human form, was the outward sign of moral perfection. As Immanuel Kant expresses it in the Kritik der Urteilskraft \$59, beauty becomes symbolic of morality: "das Schöne ist das Symbol des SittlichGuten". ${ }^{12}$ This is an appealing thought, especially if it suggests that nobility of the soul leaves its mark, embellishing the outer form and making a person appear more attractive to the onlooker.

A similar theme had appeared in Leibniz's Discours sur les beaux sentiments (1690), where the philosopher combines the moral with the aesthetic by establishing an explicit connection between noble sentiments and physical beauty. As Ursula Franke expresses it in her discussion

10 Anthony Ashley Cooper, Third Earl of Shaftesbury, Characteristics of Men, Manners, Opinions, Times (1711). Edited by Lawrence E. Klein. (Cambridge: Cambridge University Press, 1999) 172.

11 Shaftesbury, 414-415.

12 Reclam 308 
of this treatise, "Er führt die schönen Gefühle nicht ohne weiteres auf eine Neigung zum Schönen sondern auf die Verbindung von Tugend und Größe" (He does not immediately attribute beautiful feelings to an inclination towards beauty but to the connection between virtue and greatness. $^{13}$ She identifies this earlier instance as the thought implicit in Kant's subsequent formulation of the symbolic ethical function of beauty.

It seems but a small step from Kant to Schiller's statement about the moral disposition: "Mit andern Worten: seine sittliche Fertigkeit muß sich durch Grazie offenbaren." (In other words: moral capacity must reveal itself through grace). ${ }^{14}$ The bond Schiller forges between morality and visible beauty resembles Kant's formula to a certain degree, but differs from it in crucial ways. A symbol, the term Kant uses, stands in a separable relation to the object it signifies. No fundamental or compelling causal link is indicated in symbolism. But Schiller's argument claims moral consciousness as an essential precondition of physical grace. There is no accidental or artificial aspect to their union, the highest expression of which occurs in the form of the beautiful soul.

In its more extreme and literal form, however, the notion that ethical integrity is implicit in physical beauty manifests itself as physiognomy, a theory set forth in Johann Caspar Lavater's Physiognomische Fragmente (1775). ${ }^{15}$ The highly questionable principle behind this work is that a person's character can be discerned through an analysis of facial features, so that mathematically calculated proportions could give a reliable indication of a person's moral worth. This relationship is also presented as a necessary rather than a symbolic one, and its implications are rather horrifying. The bubble of popularity enjoyed by physiognomy was ultimately burst by the (notably unattractively hunchbacked) satirical writer Georg Christoph Lichtenberg in 1777, when he pointed out that since the moral struggle in the soul consists precisely in resisting the pleasures and excesses associated with the body, a causal association such as that proposed between the moral and the physical was unthinkable. But however misguided the theory, the pervasive allure

13 Ursula Franke, "Das richtige Leben und die Kunst: Die schöne Seele im Horizont von Leibniz' Philosophie“ Modern Language Notes vol. 103/3 Spring 1988. 504-518. Here 507.

14 All references to Schiller's essay are taken from Schillers Werke: Nationalausgabe, vol. 20: Philosophische Schriften 1, edited by Benno von Wiese and Helmut Koopman (Weimar: Böhlau, 1962) 67-136. Here 277.

15 Norton devotes a chapter to the cult of physiognomy, 176-209. 
of physiognomy surely ties in with the urgent Enlightenment need to define and thus promote moral behaviour in terms that had not been established by ecclesiastical asceticism or any of society's narrow traditions but were based in reason. Enlightenment thinkers sought to establish principles crafted with a non-hierarchical social application in mind, rather than aiming at a heavenly existence. Physiognomic theory is prompted by the same instinct for the reconciliation of extremes that informs Wieland's essay, even though this fusion is conceived of as occurring between understanding and emotion in the latter case, and between the ethical and the physical in the former.

The expression "schöne Seele" provides Friedrich Schiller with the opportunity to work out what happens when feelings are so trained and directed towards the good that duty and inclination become inseparably joined. In his essay Über Anmut und Würde (On Grace and Dignity, 1793) Schiller works within the established Enlightenment framework of the sovereignty of freedom and sets himself the task of adjusting the demands of the sensual desires and bringing them into line with the need for ethical limitations. He seeks to strike a balance between the temporal movement of grace and the instinctive habit that ultimately forms a moral disposition. He also deals here with the challenge put forth by physiognomy by sorting physical characteristics into two categories: the expressive ones (sprechende) and the mute ones (stumme). The expressive characteristics communicate something about the soul or character, whereas the mute ones are merely laid down by nature within the species and say nothing about individual character. ${ }^{16}$ Thus Schiller, too, allows for individual moral sensibility to become visible: "Denken wir ihn uns aber als moralische Person, so sind wir berechtigt, einen Ausdruck derselben in seiner Gestalt zu erwarten ..." (If we think of it as a moral person, we are justified in expecting an expression of the same in his physique ...). ${ }^{17}$ He does not, however, provide for the reverse procedure, as Lavater had done: our visible features do not predetermine what can be known about our moral disposition.

A little further on in his treatise, Schiller arrives at a consideration of the figure of the beautiful soul, which by now has come to sum up the goal of Schiller's search for harmony and balance between the sensual

16 Schiller's "On Grace and Dignity" in Its Cultural Context. Essays and a New Translation. Edited by Jane V. Curran and Christophe Fricker. (Rochester N.Y: Camden House, 2005) 142. 
and the ethical. ${ }^{18}$ "In einer schönen Seele ist es also, wo Sinnlichkeit und Vernunft, Pflicht und Neigung harmonieren, und Grazie ist ihr Ausdruck in der Erscheinung" (It is in a beautiful soul, then, that sensuousness and reason, duty and inclination are in harmony, and grace is their expression in appearance). ${ }^{19}$ Instinct and reason are no longer at loggerheads in this figure, and both freedom and the form established by nature can be preserved without cost to either. Because instinct has a role to play, the actions of the schöne Seele are, in Schiller's terms, unconsciously beautiful. Even a physique that nature has not blessed with beauty of form will acquire grace from within when balance or harmony is present.

For Schiller, a movable or unstable quality is an essential ingredient in the definition of the schöne Seele. This is because of the crucial importance of grace, which in his definition always involves movement. The movement must be undertaken by a conscious being but must nevertheless be instinctive. The beauty and grace of her actions is not something of which the schöne Seele is ever conscious.

In this theoretical discussion, Schiller is at pains to define the phenomenon of grace with clarity and to dispell any inexact notions. He also emphasizes the importance of moulding natural inclination in the direction of moral duty so as to form an indissoluble bond between the two. Speculation about real instances of this phenomenon is not his task here, nor does he move beyond intermittent imagery or attempt to provide a full-blown fictional description.

Goethe's beautiful soul is not really a straightforward case of fiction either. The sixth book of his Wilhelm Meisters Lehrjahre consists entirely of an autobiographical document by the hand of a woman who essentially has no other role in the whole novel: the "Bekenntnisse einer schönen Seele" (Confessions of a Beautiful Soul). The insertion of the document was a curious decision on Goethe's part, and one that had consequences for the structure, balance and plot of the novel. The confessions are based on actual documents and an actual person, a friend of his mother's, Susanna Katharina von Klettenberg, a woman whose exemplary piety and moral vigilance offered the author a path through the distractions of the youthful mind. For some readers of today, the soul-searching introspection in this book and its strong Pietist content make for something of an imperfect fit with the colourful and morally adventurous narrative that constitutes the rest of the novel, while for 
other readers it is surely downright unpalatable. And yet the narrative explanation for the inclusion of this manuscript is that it has been prescribed by a doctor as reading matter that will lessen Aurelie's psychological suffering and form an important part of her palliative care. A story of moral struggle and temptation ending in balance and serenity, the confessions offer Aurelie a point of comparison with her own life.

On the face of it there does not appear to be much overlap between Schiller's theoretical discussion of the beautiful soul as laid down in "Über Anmut und Würde" and Goethe's depiction of the character referred to as 'die schöne Seele' ${ }^{20}$ Nor is it immediately possible to attribute the differences to the events described by the autobiographical narrator of the sixth book and the necessity for them to reflect on the stages of Wilhelm's own life. Pietism's emphasis on individual devotions and the cultivation of the soul are reflected in her ability to adopt an abstract position whereby soul and body appear to be separated from one another. This division is repeated in the fact of her seclusion from society. ${ }^{21}$

In her struggle to reconcile worldly temptations with a rigid upbringing, the beautiful soul in Goethe's work alludes to Wieland's Agathon and compares her own weaknesses to his. The Confessions, as Goethe presents them, are an account of the difficulties in establishing the required balance rather than a precise description of that balance once achieved. This is one difference from Schiller's discussion of the schöne Seele: Schiller counteracts preconceptions of the schöne Seele and acknowledges the difficulties involved in establishing harmony, but he avoids the agonies of self-doubt, disappointment and disgust that Goethe graphically and convincingly evokes. Schiller's schöne Seele must surely struggle too, to maintain the state of equilibrium, but the actual process of transformation is not his principal concern in the essay. For Goethe, on the other hand, the process is of vital interest. Although his schöne Seele in Wilhelm Meisters Lehrjahre, as has often been observed, is preoccupied with self-evaluation and therefore lacks that response to others that must form part of the ethical code, the confessions themselves provide an account of Bildung, the details of which

20 Nicholas Saul, "The pursuit of the subject: literature as critic and perfecter of philosophy 1790-1830" Philosophy and German Literature 1700-1990 ...67. "This visible harmony of freedom and sensuality, duty and inclination, is 'Anmut', grace. Its incarnation is of course the beautiful soul ... whose autobiography Wilhelm Meister reads.

21 Bergengruen, 42. 
are intended to transform their reader. Wilhelm reads them, he reads them for Aurelie's benefit and they leave their mark on us as readers too.

Remarkably, Goethe's schöne Seele also seems to have been partially formed by her reading. Not only does she refer to Wieland's Geschichte des Agathon, but in her concluding words, she employs some of the terminology used by Schiller in his discussion of the schöne Seele: "Gesetz ... Trieb ... Freiheit ... eine höhere Kraft" (Law... impulse ... freedom ... a higher power). She presents herself as motivated by an impulse to progress gradually along the path towards the goal of a moral disposition. ${ }^{22}$

The idea of a schöne Seele always expresses the same objective: to create a harmony out of conflicting drives, inclinations or instincts. Wieland's examples are usually found in a more or less legendary setting: the contemporary world of an ancient writer or a fictitious ancient world constructed by Wieland himself; but the issues are clear cut and the examples vivid. Schiller's description of the schöne Seele is theoretical, and yet appealingly expressed; his beautifully crafted sentences and poetic imagery are rhetorically persuasive. The example from Goethe, which may be the best known, is also hardest to sum up. The harmonizing takes place on the narrative level, because autobiography is integrated into third-person narrative. Whereas for the schöne Seele development takes place as a result of a variety of encounters with other people, many of Wilhelm's experiences are mediated through texts, the more decisive and long lasting influences in his life coming from the characters he encounters in his reading: Tancred, Hamlet and finally the schöne Seele herself.

\section{JANE CURRAN \\ Dalhousie University}

22 See Susanne Zantop, "Eigenes Selbst und fremde Formen: Goethes "Bekenntnisse einer schönen Seele" Goethe Yearbook, vol. 3 (1986) 73-92, especially 85. The editors of the Frankfurter edition of Wilhelm Meisters Lehrjahre make a similar observation. Johann Wolfgang Goethe, Sämtliche Werke. Briefe, Tagebücher und Gespräche (Frankfurt am Main: Deutscher Klassiker, 1992) Section 1, vol. 9. 1473. 